\title{
KONSTRUKSI HUKUM DALAM PEMBUKTIAN UNSUR TINDAK PIDANA PEMBUNUHAN BERENCANA
}

(Prespektif Putusan PN Raba Bima Nomor 341/Pid.B/2014/PN.Rbi, PT Nomor 20/Pid/2015/PT.Mtr Dan Putusan Mahkamah Agung (MA) Nomor 815 K/Pid/2015)

\author{
Oleh: \\ Hajairin \\ hajairinbima@yahoo.com \\ Dosen STIH Muhammadiyah Bima
}

\begin{abstract}
:
In this research, the author saw in two court judgments which taken out by the District Court (PN) of Raba Bima, number 341/Pid.B/2014/PN.R.bi and the High Court of Mataram (PT), number 20/Pid/2015/PT.Mtr. Both of judgments are strengthen each other, it defendant is in the period of detention during 19 years in prison. However, the verdict/judgment of Supreme Court Number 815K/Pid/2015 cancelled of two court judgment which it underneath. In this case, the Judge has different view of law as the main point to be consideration to make decision for Abdul Khalik. The construction of law in this case has to be seen and translated by the concept of judgment and legal certainty, because of different decision making by District Court (PN) of Raba Bima, the High Court of Mataram and Supreme Court which is freeing Abdul Khalik from all lawsuits. Based on these situation, it need to deep analysis and critically to get the best judgment as the goal of criminal law which is born by the criminal justice system.
\end{abstract}

\section{Keywords: Konstruksi, Hukum, Tindak Pidana, Pembunuhan} Berencana

\section{Pendahuluan}

Konstruksi hukum dapat dilakukan apabila suatu perkara dimajukan kepada hakim, tetapi tidak ada ketentuan yang dapat dijalankan untuk menyelesaikan perkara tersebut, meskipun telah dilakukan penafsiran hukum. Begitu juga setelah dicari dalam hukum kebiasaan atau hukum adat, tidak ada peraturan yang dapat membawa penyelesaian terhadap kasus tersebut. Dalam hal demikian, hakim harus memeriksa lagi sistem hukum yang menjadi dasar lembaga hukum yang bersangkutan. Apabila dalam beberapa ketentuan ada mengandung kesamaan, maka hakim membuat suatu pengertian hukum (rechtsbegrip) sesuai dengan pendapatnya. 
Dalam kasus pembunuhan dengan terdakwa Abdul Khalik dan korban Muslimah di tingkat Pengadilan Negeri (PN) Raba Bima telah memutuskan perkara tindak pidana pembunuhan dengan terdakwa Abdul Khalik dengan menggunakan Pasal 340 KUHP hal inipun sesuai dengan tuntutan jaksa yang menggunakan Pasal 340 KUHP, sehingga dalam Putusan Nomor: 341/Pid.B/2014/PN.Rbi, Tanggal 2 Maret 2015 yang amarnya berbunyi sebagai berikut :

1. Menyatakan terdakwa Abdul Khalik telah terbukti secara sah dan meyakinkan bersalah melakukan tindak pidana " Pembunuhan dengan direncanakan terlebih dahulu;

2. Menjatuhkan pidana kepada terdakwa oleh karena itu dengan pidana penjara selama 19 (sembilan belas) tahun;

3. Menetapkan masa penahanan yang telah dijalani oleh terdakwa dikurangkan seluruhnya dari pidana yang dijatuhkan;

4. Memerintahkan terdakwa tetap ditahan. ${ }^{1}$

Kitab Undang-Undang Hukum Acara Pidana (KUHAP),

Pasal 67 berbunyi: “Terdakwa atau penuntut umum berhak untuk minta banding terhadap putusan pengadilan tingkat pertama kecuali terhadap putusan bebas, lepas dari segala tuntutan hukum dan putusan pengadilan dalam acara cepat" atas dasar itu kemudian dalam putusan pada tingkat banding di Pengadilan Tinggi (PT) Mataram, dalam Putusan Nomor 20/PID/2015/PT.Mtr. Dengan ketentuan Mengingat Pasal 340 KUHP dan Peraturan Perundang-undangan lainnya yang berkaitan dengan perkara ini adalah sebagai berikut;

1. Menerima permintaan banding yang diajukan olehTerdakwa dan Penuntut Umum;

2. Menguatkan putusan Pengadilan Negeri Raba Bima Nomor: 341/ Pid.B/2014/PN.Rbi, Tanggal 2 Maret 2015, yang dimintakan banding tersebut ;

3. Menetapkan penahanan yang telah dijalani oleh Terdakwa dikurangkan seluruhnya dari pidana yang dijatuhkan;

4. Memerintahkan supaya Terdakwa tetap berada dalam tahanan

5. Membebankan biaya perkara kepada terdakwa dalam kedua tingkat peradilan, yang pada tingkat banding ditetapkan sebesar Rp.2.500; (dua ribu lima ratus rupiah).

Dengan demikian antara dua putusan di atas ini saling menguatkan antara satu sama lain putusan hakim pada Pengadilan Negeri (PN) Raba Bima dan Pengadilan Tinggi Mataram (PT), samasama menggunakan Pasal 340 KUHP Dengan Ketentuan “Barang siapa sengaja dan dengan rencana lebih dahulu merampas nyawa orang lain,

${ }^{1}$ Lihat Putusan Pengadilan Negeri Raba Bima Nomor:
341/Pid.B/2014/PN.Rbi


dancam dengan pidana mati atau pidana penjara seumur hidup atau selama waktu tertentu, paling lama 20 tahun."

Dalam Konstruksi hukum bagi seorang hakim Mahkamah Agung (MA) dalam putusan Nomor 815 K/Pid/2015 telah menjatuhkan putusan bebas terhadap terdakwa Abdul Khalik dari segala tuntutan hukum dan hanya di perintahkan untuk di rehabilitasi selama satu tahun di Rumah Sakit Mataram. Dalam pertimbangan hukumnya mengatakan bahwa benar terdakwa Abdul Khalik melakukan pembunuhan, namun hal itu terdakwa lakukakan dalam keadaan jiwanya cacat dalam pertumbuhan atau ternganggu karena penyakit sesuai Pasal 44 KUHP. ${ }^{2}$

Sementara dalam ketentuan Kitab Undang-Undang Hukum Pidana (KUHP) Pasal 44 Ayat 1 dan 2 sebagai berikut:

1. Orang yang melakukan perbuatan yang tidak dapat dipertanggungkan kepadanya karena jiwanya cacat dalam pertumbuhan atau terganggu karena penyakit, tidak dipidana;

2. Bila temyala perbuatan itu tidak dapat dipertanggungkan kepadanya karena pertumbuhan jiwanya cacat atau terganggu karena penyakit, maka hakim dapat memerintahkan supaya orang itu dimasukkan ke rumah sakit jiwa, paling lama satu tahun sebagai masa percobaan.

Dalam penafsiran Pasal di diatas Penulis melihat ini menunjukan perkembangan Kejiwaan yang tidak sempurna atau Gangguan Kejiwaan Hal yang harus diteliti dan diputuskan oleh hakim untuk menunjukkan perkembangan kejiwaan yang tidak sempurna atau mengalami gangguan kejiwaan, tindak pidana yang dilakukannya merupakan akibat dari penyakit dan tindakan.

Menurut Moeljatno, yang berhubungan dengan kemampuan bertanggung jawab (toerekeningsvatbaarheid) ialah Pasal 44 Ayat (1) KUHP, yang mengatur tentang ontoerekeningsvatbaarheid (hal tidak dapat dipertanggungjawabkannya seseorang atas tindakantindakannya). ${ }^{3}$ Dalam pemahaman lain, yaitu terjemahan dari $R$. Soesilo, maka bunyi Pasal 44 Ayat (1) KUHP dapat dimaknai adalah "Barangsiapa mengerjakan sesuatu perbuatan, yang tidak dapat dipertanggungkan kepadanya karena kurang sempurna akalnya atau karena sakit berubah akal tidak boleh dihukum. ${ }^{4}$ Sementara Andi Hamzah, bunyi Pasal 44 Ayat (1) KUHP adalah sebagai berikut "Barangsiapa melakukan perbuatan yang tidak dapat dipertanggungkan kepadanya karena jiwanya yang cacat dalam pertumbuhan atau terganggu karena penyakit, tidak dipidana. ${ }^{5}$

\footnotetext{
${ }^{2}$ Lihat Putusan Mahkamah Agung (MA) Nomor 815 K/Pid/2015

${ }^{3}$ Moeljatno, 2009, Asas-Asas Hukum Pidana, Jakarta : PT Rineka Cipta,,

Hal 178

${ }^{4}$ R. Soesilo, 1996, Kitab Undang-Undang Hukum Pidana (KUHP) Serta Komentar-Komentarnya Lengkap Pasal Demi Pasal, Bogor : Politeia, Hal 60

${ }^{5}$ Andi Hamzah, 2012, KUHP \& KUHAP, Jakarta : Rineka Cipta, Hal 23
} 
Namun dengan keluaranya Putusan Mahkamah Agung (MA) Nomor 815 K/Pid/2015 yang membatalkan semua putusan pengadilan dibawahnya hal inilah yang menarik untuk penulis analisis dalam kasus ini, sehingga kita dapat memahami hakikat dalam suatu putusan pengadilan itu seperti apa sebab filosofi hukum dari putusan berkekuatan hukum tetap adalah putusan tersebut sudah tidak dapat lagi dirubah, terkecuali dengan upaya hukum luar biasa, jadi bukan berarti mengenai eksekusi putusan tetapi disinilah pemahaman hukumnya harus diperkuat melalui putusan ini.

Dengan adanya konsep Demi Keadilan Berdasarkan Ketuhanan Yang Maha Esa dan putusan pengadilan tersebut diucapkan dalam sidang yang terbuka untuk umum, maka putusan pengadilan demikian sudah mempunyai kekuatan hukum, namun apakah keadilan itu betul-betul terwujud dalam kasus yang penulis angkat dalam penelitian ini.

Lebih lanjut penulis melihat tiga putusan ini mempunyai prespektif hukum yang berbeda, putusan Pengadilan Negri (PN) Raba Bima dan Pengadilan Tinggi (PT) Mataram yang menjatuhkan hukuman 19 tahun penjara sedangkan Mahkamah Agung (MA) justru membebaskan terdakwa ABDUL KHALIK dari segala tuntutan hukum, tentu terdapat kejanggalan-kejanggalan dari pencari keadilan baik dari aspek keadilan maupun aspek lainya tentu dalam hal ini kepastian hukum dalam kasus ini. Memang dalam tiga putusan ini telah memberikan kepastian hukum dalam prespektif hukum pidana, namun yang menjadi kejanggalanya adalah pembuktian hukum unsur tindak pidana pemunuhan dalam putusan MA nomor $815 \mathrm{~K} / \mathrm{Pid} / 2015$ yang membatalkan putusan pengadilan dibawahnya atau justru PN dan PT tidak maksimal dalam persidangan sebelumnya.

Putusan hakim yang ideal adalah apabila mengandung unsur-unsur Gerechtigkeit (keadilan), Zweckmassigkeit (kemanfaatan), dan Rechtssicherheit (kepastian hukum) secara proporsional. Suatu putusan hakim harus adil, tetapi harus pula bermanfaat bagi yang bersangkutan maupun masyarakat, dan terjamin kepastian hukumnya ${ }^{6}$. Sebuah putusan diharapkan dapat memberikan kepuasaan pada semua pihak dalam suatu perkara, dengan memberikan alasan-alasan atau pertimbangan hukum yang sesuai dengan nilai-nilai kebenaran dan keadilan.

Dalam analisis ini penulis mencoba untuk melihat konstruksi hukum terhadapa pembuktian dalam unsur tindak pidana pembunuhan berencana pada Putusan PN Raba Bima Nomor 341/Pid.B/2014/PN.Rbi, PT Nomor 20/Pid/2015/PT.Mtr Dan Putusan

${ }^{6}$ Sudikno Mertokusumo, 2014, Teori Hukum (Edisi Revisi), Cahaya Atma Pustaka, Yogyakarta, Hal 24 
Mahkamah Agung (MA) Nomor 815 K/Pid/2015 dalam memberikan keadilan dan kepastian hukum.

\section{Konstruksi Hukum Bagi Hakim}

Hakim menjatuhkan pidana harus dalam rangka menjamin tegaknya kebenaran, keadilan, dan kepastian hukum bagi seseorang, jadi, bukan hanya rutinitas pekerjaan ataupun bersifat formalitas. Apabila kita kembali pada tujuan hukum acara pidana, secara sederhana adalah untuk menemukan kebenaran materil. Bahkan tujuan hukum acara pidana dalam mencari dan menemukan kebenaran materiil itu hanya merupakan tujuan antara, sebab ada tujuan akhir yaitu yang menjadi tujuan seluruh tertib hukum adalah mencapai suatu masyarakat yang tertib, damai, adil dan sejahtera.

Putusan hakim adalah suatu pernyataan (statement) yang dibuat oleh hakim sebagai pejabat negara yang diberi wewenang untuk itu dan diucapkan di muka sidang dengan tujuan untuk mengakhiri atau menyelesaikan suatu perkara antara para pihak yang bersengketa. Selain diucapkan oleh hakim, hal ini juga harus dituangkan dalam bentuk terulis yang kemudian diucapkan oleh hakim di persidangan yang dianggap sebagai putusan hakim.

Dengan Demikian Entah pada putusan pengadilan negeri (PN), Pengadilan Tinggi Maupun Di tingkat Kasasi pada Mahkamah Agung (MA) Dalam menemukan putusan yang berkeadilan pada penegakan hukum pidana tersebut.

\section{Tindak Pidana}

Dalam hukum acara pidana Putusan Pelepasan dari Segala Tuntutan Hukum (Onslaag van Alle Recht Vervolging), Putusan pelepasan terdakwa dari segala tuntutan hukum dijatuhkan oleh hakim apabila dalam persidangan ternyata terdakwa terbukti secara sah dan meyakinkan bersalah sebagaimana dalam dakwaan Penuntut Umum, tetapi diketahui bahwa perbuatan tersebut bukan merupakan perbuatan pidana, dan oleh karena itu terhadap terdakwa akan dinyatakan lepas dari segala tuntutan hukum. Hal ini diatur dalam Pasal 191 ayat (2) KUHAP.

Sudarto menjelaskan bahwa Tindak pidana adalah pelanggaran norma yang berlaku dalam masyarakat menimbulkan perasaan tidak senang yang dinyatakan dalam pemberian sanksi. ${ }^{7}$

\section{Tindak Pidana Pembunuhan Berencana}

Pembunuhan berencana dalam KUHP diatur dalam Pasal 340 adalah "Barang siapa sengaja dan dengan rencana lebih dahulu merampas nyawa orang lain, diancam karena pembunuhan dengan rencana dengan pidana mati atau pidana penjara seumur hidup atau selama waktu tertentu, paling lama dua puluh tahun". Pembunuhan

\footnotetext{
${ }^{7}$ Sudarto, 1990, Hukum Pidana 1, Yayasan Sudarto, Hal 38
} 
berencana itu dimaksudkan oleh pembentuk undang-undang sebagai pembunuhan bentuk khusus yang memberatkan, yang rumusannya dapat berupa "pembunuhan yang dilakukan dengan rencana terlebih dahulu dipidana karena pembunuhan dengan rencana". Berdasarkan apa yang diterangkan di atas, maka dapat disimpulkan bahwa merumuskan Pasal 340 KUHP dengan cara demikian, pembentuk undang-undang sengaja melakukannya dengan maksud sebagai kejahatan yang berdiri sendiri, untuk lebih lanjutnya akan dipaparkan dalam pembahasan.

Suatu perbuatan hanya dapat dipersalahkan, jika ia pada saat melakukan perbuatan itu, menghendaki akibat yang disebabkannya atau setidak-tidaknya akibat itu dapat diketahuinya terlebih dahulu. Jika pelaku pidana menghendaki akibatnya, maka kehendak itu disebut sengaja, yang dapat diketahuinya terlebih dahulu, maka terdapatlah kesalahan. ${ }^{8}$

Pembunuhan berencana ialah pembunuhan yang dilakukan oleh terdakwa dengan direncanakan terlebih dahulu, misalnya, dengan berunding dengan orang lain atau setelah memikirkan siasat-siasat yang akan dipakai untuk melaksanakan niat jahatnya itu dengan sedalam-dalamnya terlebih dahulu, sebelum tindakan yang kejam itu dimulainya.

\section{Kontruksi Hukum Ideal Yang Seharusnya Dirumuskan Oleh Hakim Mahkamah Agung Dalam Putusan Nomor 815 K/ Pid/2015}

Dalam analisisis ini penulis coba memahami atau menganalisis sesuai dengan poin penting dalam rumusan masalah di atas, tentunya yang berkaitan dengan konstruksi hukum pembuktian dalam unsur tindak pidana pemunuhan dalam Putusan Hakim Mahkamah Agung (MA) Nomor 815 K/ Pid /2015. Kemudian juga akan di kaitkan dengan putusan hakim pengadilan negeri raba bima dan pengadilan tinggi mataram, telah memenuhi prosedur dan yang seharusnya berlaku dalam jukum acara pidana. Selanjutnya konstruksi yang ideal sebagai rumusan oleh hakim MA dalam Putusan Nomor 815 K/ Pid /2015 tentu dalam memberikan kepastian dan keadilan bagi pelaku Abdul Khalik sebagai pelaku dan keluarga Muslimah sebagai korban.

Pertimbangan Hukum Hakim MA Yang Membatalkan Semua Putusan Pengadilan Di Bawahnya Dalam Kasus Pembunuhan Dengan Terdakwa Abdul Khalik, dalam konteks teori hukum yang menggambarkan tentang kekuasaan kehakiman dalam memutuskan perkara baik ditingkat PN, PT Dan MA

${ }^{8}$ Van Apeldoorn, 2001, Pengantar Ilmu Hukum, PT Pradnya Paramita, 
Undang-undang Nomor 48 Tahun 2009 tentang Kekuasaan Kehakiman dalam Lembaran Negara Republik Indonesia Tahun 2009 Nomor 157, Tambahan Lembaran Negara Republik Indonesia Tahun 2009 Nomor 5076 (untuk selanjutnya disebut UU Kekuasaan Kehakiman). Independensi diartikan sebagai bebas dari pengaruh eksekutif maupun segala Kekuasaan Negara lainnya dan kebebasan dari paksaan, direktiva atau rekomendasi yang datang dari pihak-pihak extra judisiil, kecuali dalam hal-hal yang diizinkan oleh UndangUndang. Demikian juga meliputi kebebasan dari pengaruh-pengaruh.

Sedangkan menurut Paulus Lotulung yurisprudensi adalah putusan badan peradilan (hakim) yang diikuti secara berulan-ulang dalam kasus yang sama oleh para hakim lainnya sehingga karenanya dapat disebut pula sebagai "Rechtersrecht" (hukum ciptaan hakim/ peradilan). ${ }^{9}$

Dalam pertimbangan hukum hakim Mahkamah Agung (MA) dalam kasus pembunuhan dengan terdakwa Abdul Khalik yang membunuh anak kandungnya sendiri dalam putusan pengadilan negeri terdakwa melakukan pembunuhan dengan direncanakan terlebih dahulu. Hakim mahkamah agung (MA) dalam putusan nomor $815 \mathrm{~K} /$ Pid / 2015 justru membatalkan putusan pengadilan dibawahnya dengan pertimbangan hukum bahwa terdakwa melakukan pembunuhan anak kandungnya sendiri bernama MUSLIMAH dalam keadaan gangguan jiwanya cacat dalam pertumbuhan sesuai dengan pasal 44 Kitab Undang-Undang Hukum Pidana (KUHP) yang berbunyi sebagai berikut :

1) Barang siapa melakukan perbuatan yang tidak dapat di pertanggungkan kepadanya karena jiwanya cacat dalam pertumbuhan atau terganggu karena penyakit, tidak dipidana;

2) Jika ternyata pertumbuhan itu tidak dapat di pertanggungkan kepada pelakunya karena pertumbuhan jiwanya cacat atau terganggu karena penyakit maka hakim dapat memerintahkan supaya orang itu dimasukan kerumah sakit jiwa paling lama satu tahun sebagai waktu percobaan;

3) Ketentuan ayat 2 hanya berlaku bagi mahkamah agung, pengadilan tinggi, dan pengadilan negeri.

Terdakwa Abdul Khalik hanya di perintahkan untuk di rehabilitasi selama satu tahun sesuai dengan pasal 44 KUHP ayat 2, namun dari pengamatan atau analisis penulis dalam putusan Mahkamah Agung (MA) nomor 815 K/ Pid /2015, telah sesuai dengan

9 Paulus Effendie Lotulung, "Yurisprudensi Dalam Perspektif Pengembangan Hukum Administrasi Negara di Indonesia," (Pidato Pengukuhan Diucapkan Pada Upacara Penerimaan Jabatan Sebagai Guru Besar Ilmu Hukum Administrasi Negara pada Fakultas Hukum Universitas Pakuan, Bogor, 24 September 1994), Hal 3 
prosesur sistim peradilan pidana dan sesuai juga dengan kondisi kasus dalam tindak pidana pembunuhan. Saksi ahli telah menunjukan bahwa terdakwa dalam keadaan terganggu jiwanya atau cacat dalam perkembanganya, dan bukti hukum lain adalah hasil visum nomor 441/731/RSJP/VI/2014 tertanggal 23 juni 2014 dan ditanda tangani oleh dokter Dr Yolly Dahlia, SP.KJ yang jelas mengatakan terdakdawa dalam keadaan gangguan kejiawaan, dan semua itu ada dalam pertimbangan hukum hakim pengadilan negeri (PN) Raba Bima.

Kekuasaan kehakiman yang merdeka dan mandiri harus terwujud dalam keseluruhan proses penegakan hukum pidana. Dengan kata lain, sistem peradilan pidana pada hakikatnya merupakan sistem penegakan hukum pidana atau sistem kekuasaan kehakiman di bidang hukum pidana. ${ }^{10}$ Kekuasaan kehakiman dalam arti luas, maka kekuasaan kehakiman tidak hanya berarti "kekuasaan mengadili", tetapi mencakup kekuasaan menegakan hukum dalam seluruh proses penegakan hukum. ${ }^{11}$

Kalau melihat sejenak konstruksi dalam merumuskan atau mempertimbangkan serta prosedur yang ideal dalam proses putusan MA nomor $815 \mathrm{~K} /$ Pid /2015 maka tentu akan bersepakat dengan susuna atau prosedur yanga ada, karena dalam kajian atau analisis penulis bahwa semua tiga putusan ini tidak ada yang bertentangan dengan KUHAP dan peraturan perundangang-undangan yang berlaku hanya saja kelalain hakim dalam melihat bukti hukum dalam proses persidangan. Kemudian juga pemilihan pasal untuk dijadikan dasar hukum juga mungkin tidak berjalan maksimal sesuai dengan bukti hukum yang ada.Jadi tidak ada masalah dalam prosedur dalam tiga putusan di atas kalau kita kaitkan dalam hukum acara pidana.

1. Konstruksi Hukum Yang Di Lakukan Oleh Hakim Pengadilan Negeri Raba Bima Nomor 341/Pid.B/2014/PN.Rbi (PN) dan Pengadilan Tinggi Nomor 20/Pid/2015/PT.Mtr Sesuai Dengan Prosedur Hukum Acara Pidana

Dalam persidangan tingkat pertama yaitu di pengadilan negeri (PN) Raba Bima melihat pertimbanganya hukum hakim bahwa terdakwa abdul khalik telah terbukti melakukan pembunuhan dengan di rencanakan terlebih dahulu, tentunya pertimbangan ini berdasarkan pembuktian atau bukti-bukti hukum dan di temukan oleh hakim pengadilan negeri (PN), dan hal inipun sesuai dengan tuntutan Kejaksaan Negeri (Kejari) Raba Bima yang menggunakan Pasal 340. Dengan demikian pengadilan negeri (PN)memutuskan menggunakan Pasal 340

10 Erna Dewi, Sistem Peradilan Pidana Indonesia: Dinamika dan Perkembangan,(Yogyakarta: Graha Ilmu, 2014), hal. 64

11 Barda Nawawi Arief, Masalah Penegakan Hukum dan Kebijakan Hukum Pidana dalam Penanggulangan Kejahatan, Jakarta Kencana, , 2014, Hal 34 
KUHP yang berbunyi sebagai berikut :"Barang siapa dengan sengaja dan dengan rencana terlebih dahulu merampas nyawa orang lain, diancam karena pembunuhan dengan rencana, dengan pidana mati atau pidana penjara seumur hidup atau selama waktu tertentu, paling lama dua piluh tahun".12

Apa yang di gambarkan dalam dalam ketentuan Pasal 340 diatas ini adalah mencerminkan kesengjaan dalam melakukan tindak pidana pembunuhan seperti yang dijelaskan oleh Adami Khazawi bahwa Antara unsur subyektif sengaja dengan wujud perbuatan menghilangkan terdapat syarat yang harus dibuktikan, ialah pelaksanaan perbuatan menghilangkan nyawa (orang lain) harus tidak lama setelah timbulnya kehendak (niat) untuk menghilangkan nyawa orang lain itu. ${ }^{13}$

Terdakwa Abdul Khalik di jatuhi pidana 19 tahun penjara dalam putusan nomor 341/ Pid.B/2014/PN.Rbi, Dalam hal ini Hakim pengadilan negeri (PN) ketika penulis membaca 9 kali hatam dalam putusanya bahwa memang bukti-bukti hukum yang mengarah kepada pembelaan terdakwa di abaikan oleh hakim dan itu tidak di jadikan sebagai pertimbangan hukum. Misalnya keterangan saksi ahli psikologi dan hasil visum menunjukan terdakwa melakukan pembunuhan terhadap anak kandungnya dalam keadaan gangguan jiwa.

Selanjutnya dalam tingkat banding hakim pengadilan tinggi (PT) mataram,juga menggunakan Pasal 340 itu terlihat dalam putusan nomor 20 / PID / 2015 / PT. MTR yang kembali menguatkan putusan pengadilan negeri raba bima.Tidak ada yang janggal memang karena karena hanya melanjutkan bukti hukum padan tingkat PN. ${ }^{14}$ Sampai dalam tingkat kasasi di MA membatalkan semua putusan pengadilan di bawahnya, tentunya tiga putusan ini menunjukan ketidak adilan dalam sistim peradilan pidana. Sebab tindak pidana pembunuhan berencana seperti dalam Pasal 340 KUHP Ancaman pidana pada pembunuhan berencana ini lebih berat dari pada pembunuhan yang ada pada Pasal 338 dan 339 KUHP bahkan merupakan pembunuhan dengan ancaman pidana paling berat, yaitu pidana mati, di mana sanksi pidana mati ini tidak tertera pada kejahatan terhadap nyawa lainnya, yang menjadi dasar beratnya hukuman ini adalah adanya perencanaan terlebih dahulu. Selain diancam dengan pidana mati, pelaku tindak pidana

\footnotetext{
${ }^{12}$ Lihat Pasal 340 Kitab Undang-Undang Hukum Pidana (KUHAP)

${ }^{13}$ Chazawi, Adami, Kejahatan Terhadap Tubuh dan Nyawa, (Jakarta: Raja Grafindo Persada, 2004), hal. 55

${ }^{14}$ Lihat Putusan Pengadilan Tinggi Nomor 20 / PID / 2015 / PT. MTR
} 
pembunuhan berencana juga dapat dipidana penjara seumur hidup atau selama waktu tertentu paling lama dua puluh tahun.

Hakim Harusnya Menjadikan pertimbangannya sebagai penemuan hukum oleh seorang hakim dalam memutuskan perkara, sebab hakim tidak boleh menjadikan tekanan sosial sebagai bagian dari pertimbangan tersebut, sehingga apa yang diputuskan oleh hakim di tingkat PN Dan PT Haruslah Memberikan perlindungan dan keadilan bagi pihak korban maupun terdakwa dalam suatu perkara dalam peradilan pidana, dalam hal ini adalah kasus pembunuhan berencana yang di lakukan oleh Abdul Khalik dengan konsep sebagai saran dalam pemenuhan dalam hukum pidana yang berwibawa.

Penemuan hukum lazimnya diartikan sebagai proses pembentukan hukum oleh hakim atau petugas-petugas hukum lainnya yang diberi tugas melaksanakan hukum terhadap peristiwa-peristiwa hukum yang konkrit. ${ }^{15}$

Sebagaimana peraturan perundang-undangan ada susunan hirarki perundang-undangan, maka sumber utama penemuan hukum juga ada hirarki atau tingkat-tingkatannya, yaitu berturut-turut sbb : peraturan perundang-undangan, kemudian hukum kebiasaan, yurisprudensi, perjanjian internasional barulah doktrin. Dalam ajaran penemuan hukum undang-undang diprioritaskan atau didahulukan dari sumbersumber hukum lainnya. Kalau hendak mencari hukumnya, arti sebuah kata, maka dicarilah terlebih dahulu dalam undangundang. Hal ini disebabkan karena undang-undang bersifat otentik dan berbentuk tertulis, yang lebih menjamin kepastian hukum. ${ }^{16}$

Dengan ketentuan inilah hakim Pengadilan Negeri (PN) dan hakim Pengadilan Tinggi (PT) sebagai bagian yang tidak terpisahkan dalam mewujudkan keadilan dalam penegakan hukum pidana seperti bagi terdakwa abdul khalik dalam penelitian ini.

\section{Simpulan}

Dengan melihat pembahasan diatas maka dapat di simpulkan dalam kesimpulan ini sebagai berikut:

1. Antara dua putusan Pengadilan Negeri (PN) Raba Bima nomor 341/ Pid.B/2014/PN.Rbi dan putusan pengadilan tinggi mataram (PT) nomor 20 / PID / 2015 / PT. MTR. saling

15 Sudikno Mertokusumo, Dan A. Pitlo, Bab - Bab Tentang Penemuan Hukum, cet. I, (Tanpa Tempat : Citra Aditya Bakti, 1993,), hal. 4

16 Sudikno Mertokusumo, Penemuan Hukum Sebagai Pengantar, (Yogyakarta: Liberty, 1996), hal. 48 
menguatkan bahwa terdakwa tetap berada dalam tahanan dengan hukuman 19 tahun penjara.

2. Dalam putusan MA nomor $815 \mathrm{~K} /$ Pid /2015 membatalkan semua putusan pengadilan dibawahnya Tiga putusan ini mempunyai pandangan hukum yang berbeda, putusan Pengadilan Negri (PN) Raba Bima dan Pengadilan Tinggi (PT) Mataram yang menjatuhkan hukuman 19 tahun penjara sedangkan Mahkamah Agung (MA) justru membebaskan terdakwa ABDUL KHALIK dari segala tuntutan hukum, tentu terdapat kejanggalan-kejanggalan dari pencari keadilan baik dari aspek keadilan maupun kepastian hukum.

3. Upaya hukum merupakan suatu sarana baik bagi pihak terdakwa maupun penuntut umum untuk mencari putusan yang dirasa adil bagi mereka, sehingga dalam upaya hukum inilah kedua belah pihak akan kembali menguatkan argumentasi hukum mereka untuk mendapatkan putusan seadil-adilnya bagi mereka.

\section{Daftar Pustaka}

Moeljatno, 2009, Asas-Asas Hukum Pidana, Jakarta : PT Rineka Cipta

R. Soesilo, 1996, Kitab Undang-Undang Hukum Pidana (KUHP) Serta Komentar-Komentarnya Lengkap Pasal Demi Pasal, Bogor : Politeia

Andi Hamzah, 2012, KUHP \& KUHAP, Jakarta : Rineka Cipta

Sudikno Mertokusumo, 2014, Teori Hukum (Edisi Revisi), Cahaya Atma Pustaka, Yogyakarta

Sudarto, 1990, Hukum Pidana 1, Yayasan Sudarto

Van Apeldoorn, 2001, Pengantar Ilmu Hukum, PT Pradnya Paramita, Jakarta

Paulus Effendie Lotulung, "Yurisprudensi Dalam Perspektif Pengembangan Hukum Administrasi Negara di Indonesia," (Pidato Pengukuhan Diucapkan Pada Upacara Penerimaan Jabatan Sebagai Guru Besar Ilmu Hukum Administrasi Negara pada Fakultas Hukum Universitas Pakuan, Bogor, 24 September 1994

Erna Dewi, 2014, Sistem Peradilan Pidana Indonesia (Dinamika dan Perkembangan), Graha Ilmu, Yogyakarta

Barda Nawawi Arief, 2014, Masalah Penegakan Hukum dan Kebijakan Hukum Pidana dalam Penanggulangan Kejahatan, Penerbit : Kencana, Jakarta

Chazawi, Adami, 2004, Kejahatan Terhadap Tubuh dan Nyawa, (Jakarta: PT. Raja Grafindo Persada

Sudikno Mertokusumo, Dan A. Pitlo, 1993, Bab - Bab Tentang Penemuan Hukum, cet. I, (Tanpa Tempat: PT. Citra Aditya Bakti 
Sangagi: Jwernal Pemilizan Syariah dan Hakum

Volume I Nomor 1 Maret 2017

Sudikno Mertokusumo, 1996, Penemuan Hukum Sebagai Pengantar, Liberty, Yogyakarta 